\title{
PREFACE
}

\section{Years of the Journal of Prisoners on Prisons: Still Writing As Resistance Justin Piché}

For 25 years, the Journal of Prisoners on Prisons (JPP) has been a prisoner written, academically oriented and peer reviewed, non-profit journal, based on the tradition of the penal press. It brings the knowledge produced by prison writers together with academic arguments to enlighten public discourse about the current state of carceral institutions. This is particularly important because with few exceptions, definitions of deviance and constructions of those participating in these defined acts are incompletely created by social scientists, media representatives, politicians and those in the legal community. These analyses most often promote selfserving interests, omit the voices of those most affected, and facilitate repressive and reactionary penal policies and practices. As a result, the $J P P$ attempts to acknowledge the accounts, experiences, and criticisms of the criminalized by providing an educational forum that allows women and men to participate in the development of research that concerns them directly. In an age where 'crime' has become lucrative and exploitable, the $J P P$ exists as an important alternate source of information that competes with popularly held stereotypes and misconceptions about those who are currently, or those who have in the past, faced the deprivation of liberty.

- www.jpp.org

$\mathrm{T}$ he first issue of the $J P P$ went to print in 1988. In the quarter century that has followed, the journal has published 22 volumes and 34 issues - with another general issue forthcoming this year - documenting the experiences of imprisonment and the socio-politics of incarceration as prison populations across the world soared. Penal abolitionism (e.g. Sauvé, 1988) and reform (e.g. Dey, 2011), the colonization of indigenous peoples (e.g. Ms. Cree, 1994) and people of colour through imprisonment (e.g. Eribo, 2005), poverty, profiteering and incarceration (e.g. Ransome, 2011), the criminalization of women (e.g. Mayhew, 1988), victimization (e.g. Wright, 1998), capital punishment (e.g. Abu-Jamal, 1990/1991), political imprisonment (e.g. Flynn 1996/1997) and torture (e.g. Saeideh, 2010), marionization (e.g. Griffin, 1993) and solitary confinement (e.g. Bubba-B, 
2006), health (e.g. Huckelbury, 2006) and mental health behind bars (e.g. Collins, 2008), (in)security (e.g. Larsen et al., 2008) and immigration detention (e.g. Lekarowicz, 2008), prison education (e.g. Salah-EL, 1992), carceral tours (e.g. Minogue, 2003), prison research (e.g. Taylor, 2009), prisoner writing (e.g. Hassine, 1999) and resistance (e.g. Bryden, 1990/1991), are among the many themes addressed by our contributors. While many of our authors come from the United States, the world's leading prison nation, and Canada where the journal is housed, we have also published pieces written by individuals incarcerated in Africa, Asia, Central and South America, Europe, the Middle East and Oceania, which reflects the global entrenchment of the deprivation of liberty.

The JPP and its readership owes a debt of gratitude to prison writers who have made visible their experiences and understandings of the world that many seldom encounter because of the significant barriers to, and real consequences for, exercising their right to free speech (e.g. McMaster, 1999). Bereft of many of the resources most writers take for granted and often perpetually under threat of retribution - whether it be from 'correctional' administration and staff, fellow prisoners, punishment fetishists outside prison walls, and the long list of other proponents of authoritarianism, pain and exclusion - their persistence and courage is remarkable (see Piché et al., forthcoming).

With committed writers, along with the support of 1) our publishers and their staff who have provided advice on production matters, 2) the universities that have hosted the publication and provided the intellectual space for the project to flourish, 3) the members of our Editorial Board who have offered feedback to authors with the goal of enriching their contributions, and 4) the volunteers who have worked tirelessly on the various facets of our operations over the years, the important work of the journal has been made possible. As we recommit ourselves to working towards the eradication of state repression in all of its guises, the JPP will continue its project of Writing As Resistance (Gaucher, 2002).

\section{ENDNOTES}

* Portions of this short preface were presented as part of Justin Piché's opening remarks at an event celebrating the $25^{\text {th }}$ anniversary of the JPP held on 3 May 2013 as part the Critical Perspectives: Critical Criminology and Social Justice - Third National Conference at the University of Ottawa. The event also featured remarks from Bob 
Gaucher - a founding member of the journal's Editorial Board - who discussed the origins of the publication, as well as observations from JPP Associate Editors Charles Huckelbury and Susan Nagelsen on the importance of writing for prisoners and prison writing as an educational tool. The JPP would like to thank the Faculty of Social Sciences at the University of Ottawa for sponsoring this celebration through its Research Events Program.

\section{REFERENCES}

Abu-Jamal, Mumia (1990/1991) “A Blast Into Dark Immortality”, Journal of Prisoners on Prisons, 3(1\&2): 65-70.

Bryden, Robert (1990/1991) "Remembering Prison Justice Day", Journal of Prisoners on Prisons, 3(1\&2): 89-92.

Bubba-B (2006) "Life in the SHU", Journal of Prisoners on Prisons, 15(1): 17-19.

Collins, Peter (2008) "The Continuing Story of Spiegelgrund: Mental Health, Compassion, Awareness and Incarceration”, Journal of Prisoners on Prisons, 17(2): 6-15.

Dey, Eugene (2011) "Cauldron of Solitude", Journal of Prisoners on Prisons, 20(2): $35-46$.

Eribo, Osadolor (2005) “Another Face of Slavery", Journal of Prisoners on Prisons, $14(1)$.

Flynn, Ned (1996/1997) "Birth of the Blanket Protest", Journal of Prisoners on Prisons, 7(1): 65-68.

Gaucher, Bob (ed.) (2002) Writing as Resistance: The Journal of Prisoners on Prisons Anthology (1988-2002), Toronto: Canadian Scholars' Press.

Griffin, Eddie (1993) "Breaking Men's Minds: Behavior Control and Human Experimentation at the Federal Prison in Marion, Illinois", Journal of Prisoners on Prisons, 4(2): 17-28.

Hassine, Victor (1999) "Letter to Joanna", Journal of Prisoners on Prisons, 10(1\&2): 40-45.

Huckelbury, Charles (2006) "No Farewells", Journal of Prisoners on Prisons, 14(2): 6-9.

Larsen, Mike, Sophie Harkat and Mohamed Harkat (2008) "Justice in Tiers: Security Certificate Detention in Canada", Journal of Prisoners on Prisons, 17(2): 31-46.

Lekarowicz, Joe (2008) "Bush”, Journal of Prisoners on Prisons, 17(2): 47-52.

Mayhew, Jo-Ann (1988) "Corrections is a Male Entreprise", Journal of Prisoners on Prisons, 1(1): 11-22.

McMaster, Gregory J. (1999) "Maximum Ink", Journal of Prisoners on Prisons, 10(1\&2): 46-52.

Minogue, Craig (2003) "Human Rights and Life as an Attraction in a Correctional Theme Park", Journal of Prisoners on Prisons, 12: 44-57.

Ms. Cree (1994) "Entrenched Social Catastrophe", Journal of Prisoners on Prisons, 5(2): 45-48.

Piché, Justin, Bob Gaucher and Kevin Walby (forthcoming) "Facilitating Prisoner Ethnography: An Alternative Approach to 'Doing Prison Research Differently"', Qualitative Inquiry. 
Ransome, Chas (2011) "Projects to Prisons: The Modern Day Plantations", Journal of Prisoners on Prisons, 20(2): 102-105.

Saeideh (2010) "With My Child in Jail", Journal of Prisoners on Prisons, 19(2): 31-48.

Saleh-EL, Tiyo Attallah (1992) "Attaining Education in Prison Equals Prisoner Power", Journal of Prisoners on Prisons, 4(1): 45-52.

Sauvé, Rick (1988) "Prison Abolition: The Need for Decriminalization", Journal of Prisoners on Prisons, 1(1): 39-44.

Taylor, Jon Marc (2009) "Diogenes Still Can’t Find His Honest Man", Journal of Prisoners on Prisons, 18(1\&2): 91-110.

Wright, Paul (1998) “"'Victims' Rights” As a Stalkinghorse for State Repression”, Journal of Prisoners on Prisons, 9(2): 17-22. 